\title{
EFFECT OF COVERING MATERIAL AND SHADING ON INTERIOR LIGHT INTENSITY IN POLY-GREENHOUSES
}

\author{
H. S. Abdel-Galil*
}

ABSTRACT

The objective of this research was to examine the influence of two different poly-greenhouse covering material types and their properties on the interior light intensity to choose the proper one for covering under Fayoum depression climatic conditions. Measurements of global solar radiation (GSR) and light intensity were made inside and outside six poly-greenhouse-covered prototype structures (Quonset-style). Each prototype structure was $1.0 \mathrm{~m}$ length, $1.0 \mathrm{~m}$ width and $0.8 \mathrm{~m}$ height. Two small doors in the narrow sides of each prototype were kept open during the day-light for natural ventilation. Results showed that the average transmittance in GSR of both new white polyethylene films and new black screen shade net sheets were $74.05 \%$ and $55.45 \%$, respectively. Exposure the poly-greenhouse cover to the climatic conditions reduced its transmittance to global solar radiation (GSR). The relative losses of GSR transmittance were $13.96 \%$ and $17.64 \%$ for both old-cleaned and olddirty polyethylene films, respectively, as compared with the new polyethylene film (74.05\%). The average losses of GSR transmittance were $12.93 \%$ and $19.42 \%$ for both old-cleaned and old-dirty black screen shade net, respectively, as compared with the new black screen shade net cover (55.45\%). The new white polyethylene films and new black screen shade net sheets reduced the interior light intensity of the prototypes by an average of $18.3 \%$ and $68.4 \%$ as compared with the average exterior light intensity, respectively. In addition, old-cleaned and old-dirty polyethylene films reduced the interior light intensity by an average of $20.8 \%$ and $34.8 \%$ as compared with the identical new white polyethylene film, respectively. While, old-cleaned and old-dirty black screen shade net reduced the interior light intensity by an average of $27.3 \%$ and $39.9 \%$ as compared with the identical new black screen shade net, respectively.

*Assoc. Prof. of Agric. Eng., - Fac. of Agric. - Fayoum University. 


\section{INTRODUCTION}

7 he greenhouses are usually covered with material (i.e., glass or plastic) that have the ability to transmit light that provides

Lessential energy for plant growth and production. Light is one of the most important environmental parameters that represent the climate of the greenhouse. Although light is fundamental to greenhouse, it is one of the most variable inputs and challenging. Light requirements and the climatic effects on it must be considered at all stages of greenhouse design and orientation. Not all components of the light spectrum are useful for plant growth and development. Plants use visible light or more specifically, photosynthetically active radiation (PAR), the group of light wavelengths between $400-700 \mathrm{~nm}$ as the main wavelengths during the process of photosynthesis. Thus, the poly-greenhouse cover should have a high transmittance for PAR to optimize plant growth and development.

Smith et al. (1984) indicated that total radiant density, the radiant flux density and radiation spectra were typically reduced inside the polygreenhouses covered by the plastic and different density shade cloths. The ploy-greenhouse cover material reduces the transmission of the solar radiation and effects on the quantity and quality of light available to the plants. Nijskens et al. (1990) mentioned that testes were carried out on polyethylene (PE) plastic films for a weathering period of one year showed a little decrease $(2-4 \%)$ of the transmittance in the different range of solar radiation band (280nm to $2500 \mathrm{~nm}$ wavelength). Jaffrin $\boldsymbol{e t}$ al. (1993) concluded that condensation on conventional plastic film is constituted by hemispherical drops. In this case, its transmittance is lowered than a dry film by about 5\%. Lozano et al. (1996) emphasized the importance of good solar radiation transmission in increasing greenhouse crop production. In addition, the climatic factors such as air temperature and relative humidity are indirectly affected by the greenhouse cover material. Papadakis et al. (2000) noticed that the transmittance of the poly-greenhouse cover is affected by dust, ageing and condensation. Thus, poly-greenhouse cover should be washed regularly to remove dust. 
Steven (2004) indicated that wavelengths of non-visible energy known as infra-red (600-700nm) can inhibit stem elongation and branching of plants, and leaves are sometimes smaller and thicker. This results in a lessening of flowering in short-day plants, but promotion of flowering in long-day plants. Far-red radiation (700-800nm) leads to an increase in stem elongation, and eliminating the far-red part of the solar spectrum can produce shorter plants. Droplets that form on the inside of polygreenhouse covers due to condensation reduce light transmission by 15 $30 \%$ and have negative impacts on plant quality and growth. Condensation also increases the risk of disease. Larcher (2003) and Pinto et al. (2006) reported that the intensity, duration, direction, and spectral quality of light radiation that plant receives have an effect on photosynthesis, flowering, climate response, and plant photo morphogenesis. In response to light conditions, plants can control their rate of evapotranspiration and water uptake, their internodes length, their leaves size, count, orientation, and chloroplast density, as well as determine the optimum timing for flowering and other physiological processes. Wikipedia (2007) indicated that one of the most aspects of poly-greenhouse design is to provide a covering with controlled differences between the transparency in the solar radiation band $(280 \mathrm{~nm}$ to $2500 \mathrm{~nm}$ wavelengths) and the terrestrial thermal radiation band (5000 $\mathrm{nm}$ to $35000 \mathrm{~nm}$ ) for the purpose of either raising or lowering the temperature inside the greenhouse. El-Nono et al. (2008) indicated that new yellow and blue polyethylene (PE) films (150 micron thickness) reduced the average indoor light intensity by an average of $23.25 \%$ and $36.98 \%$ as compared with the average outdoor light intensity, respectively.

Agrus Control Systems Ltd. (2010) mentioned that a single layer of polyethylene film has higher transmittance values of light and long wave radiation, IR $<700 \mathrm{~nm},(83-89 \%$ and $71-80 \%$, resp. $)$, comparing with the corresponding values for a double layer of polyethylene film (76 and $63 \%$, resp.). Some seeds require specific light conditions to break dormancy and germinate. Poly-greenhouses raised plants often look quite different from genetically identical outdoor specimens. This is due to 
their response to climate differences, including the quantity, quality and duration of light they receive. Abdel-Galil (2010) indicated that polygreenhouse with single layer of polyethylene was found more suitable for seedlings germination, plant growth and yield of tomato than those with the other shading ratios and open field condition during the winter months. Poly-greenhouse covered only by black screen sheets (especially with $63 \%$ or $75 \%$ shading ratios) was found more suitable for better seedlings germination, plant growth and yield of tomato than this with $25 \%$ shading ratio and open field condition in the summer months.

This major aim of this research is to study the effect of different polyethylene cover properties on the interior light intensity of the polygreenhouse, which is the most common and lowest cost covering, and it is used extensively under Fayoum depression climatic conditions.

\section{MATERIALS AND METHODS}

\section{Experimental prototypes:}

Six similar experimental poly-greenhouse prototypes were designed and constructed. Each prototype is a Quonset-Style, which is the most common greenhouse structure. All the prototypes made of steel pipes (1.2 $\mathrm{cm}$ diameter), and the dimensions of each prototype is $1.0 \mathrm{~m}$ long, $1.0 \mathrm{~m}$ width and $0.8 \mathrm{~m}$ height. The total surface area of each prototype is $3.2 \mathrm{~m}^{2}$, with a net floor surface area of $1.0 \mathrm{~m}^{2}$. To maintain the durability of structural frame and the prototype covering materials, a tension galvanized wires $(0.2 \mathrm{~cm}$ diameter $)$ were tied and fixed throughout the pipes and the curvatures of the greenhouse prototypes frames. To study the influence of different poly-greenhouse covering types and their properties on the interior light intensity of the greenhouse (Li), three prototypes were covered by white single layer polyethylene films (PE) of a $200 \mu \mathrm{m}$ thickness. The other three prototypes were covered with an external black screen shade net sheets (63\% shading ratio). For both types of the covering material, one of the three prototypes was covered by a new cover and the other two prototypes were covered by old-cleaned and old-dirty covers (one year's old). The treatments followed and their specifications are shown in Table (1). 


\begin{tabular}{|c|c|}
\hline \multicolumn{2}{|l|}{ Table (1): The treatments and their specifications. } \\
\hline Treatments & \multicolumn{1}{c|}{ Specifications } \\
\hline & Type 1 - polyethylene-covers (PE) \\
\hline T1 & Fully covered with new white film sheets. \\
\hline T2 & Fully covered with old-cleaned white film sheets. \\
\hline T3 & Fully covered with old-dirty white film sheets. \\
\hline & Type 2 - black screen shade net \\
\hline T4 & Fully covered with new black screen shade net. \\
\hline T5 & Fully covered with old-cleaned black screen shade net. \\
\hline T6 & Fully covered with old-dirty black screen shade net \\
\hline T7 & Ambient conditions (control). \\
\hline
\end{tabular}

2. Meteorological Conditions measuring: The global solar radiation $(\mathrm{G}$, $\mathrm{Mj} . \mathrm{m}^{-2} \cdot \mathrm{h}^{-1}$ ) and light intensity ( $\mathrm{L}, \mathrm{lux}$ ) were measured daily from $8 \mathrm{am}$ to $6 \mathrm{pm}$ inside and outside the poly-greenhouse prototypes during the experimental period as follows:

2.1. Solar radiation: The solar radiation intensity was measured daily every one hour interval outside and inside the poly-greenhouse prototypes, using a data acquisition system with an accuracy of $0.1 \mathrm{~W} / \mathrm{m}^{2}$.

2.2. Light intensity: A digital Luxmeter (unit: lux, measuring 1-150000 lux, with an accuracy of 1 lux), was used to record the light intensity inside and outside the poly-greenhouse prototypes every one hours interval.

3. Experimental procedure: All the experimental prototypes were placed on open place at El-Azab village, which is located at $5 \mathrm{Km}$ south of Fayoum city, Egypt, $\left(29^{\circ} 10^{\prime} \mathrm{N}\right.$ Latitude and $30^{\circ} 18^{\prime} \mathrm{E}$ Longitude).and 
exposed to atmospheric conditions. The global solar radiation and light intensity were measured at the center of each poly-greenhouse prototype. The ventilation system was a natural, where, there are two small doors in the narrow sides of each prototype, which kept open during the day-time (from 8 am to sunset). During the experimental periods, all the polygreenhouse prototypes were kept under the same orientation and environmental conditions.

\section{RESULTS AND DISCUSSIONS}

The following items may be appearing the average hourly transmitted global solar radiation (GSR) and light intensity inside the greenhouse prototypes as affected by the type and aging of covering materials.

\section{Solar Radiation:}

1.1 Effect of new cover types on transmittance of solar radiation: The hourly average total solar radiation incident on the horizontal surface and transmitted into poly-greenhouse prototypes for Fayoum, Egypt (May, 2012) was measured and the results are listed in Table (2) and graphically illustrated in Figures (1) through (3). The obtained results showed that the hourly average transmitted global solar radiation (GSR) into the polygreenhouse prototypes during the day-time were different in each prototype being affected mainly by the type and age of covering material. It's clear that, all trends of transmitted solar radiation into the greenhouse prototypes were below the incident solar radiation curve during the period from 8 am to sunset, and the transmitted solar radiation curves followed the same trend of the incident solar radiation curve for both types of the covering materials. As shown from Table (1) and Fig. (1), the hourly average transmitted global solar radiation (GSR) in both new white polyethylene films and new black screen shade net sheets (63\% shading ratio) were $74.05 \%$ and $55.45 \%$, respectively. Finally, we can say that, shading caused to decrease the transmittance of solar radiation, and thus, decrease the light intensity, temperatures and others environmental parameters inside the greenhouse during the day-time from sunrise to sunset. From the obtained results, we can say that, shading can be adequate and satisfactory for growth and production of some plants during the hot weather, especially at the summer months. 


\begin{tabular}{|c|c|c|c|c|c|c|c|}
\hline \multicolumn{8}{|c|}{$\begin{array}{l}\text { Table (2): Average Hourly Solar Radiation Incident on a Horizontal } \\
\text { Surface and Transmitted into Poly-greenhouse for Fayoum, } \\
\text { Egypt for the Month of May, 2012. }\end{array}$} \\
\hline \multirow{3}{*}{$\begin{array}{l}\text { Day- } \\
\text { Time } \\
\text { (h) }\end{array}$} & \multirow{3}{*}{ 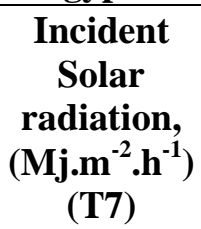 } & \multicolumn{6}{|c|}{$\begin{array}{c}\text { Transmitted solar radiation into poly-greenhouse } \\
\text { prototypes, }\left(\mathrm{Mj}_{\mathrm{j}} \mathrm{m}^{-2} \cdot \mathrm{h}^{-1}\right)\end{array}$} \\
\hline & & \multicolumn{3}{|c|}{$\begin{array}{l}\text { Single layer polyethylene } \\
\text { (Type 1) }\end{array}$} & \multicolumn{3}{|c|}{$\begin{array}{c}\text { Black Screen shade net } \\
\text { (Type 2) }\end{array}$} \\
\hline & & T1 & $\mathbf{T 2}$ & T3 & T4 & T5 & T6 \\
\hline 8 & 1.84 & 1.37 & 1.18 & 1.13 & 1.02 & 0.89 & 0.83 \\
\hline 9 & 2.36 & 1.78 & 1.52 & 1.45 & 1.31 & 1.14 & 1.06 \\
\hline 10 & 2.76 & 2.06 & 1.76 & 1.69 & 1.53 & 1.33 & 1.24 \\
\hline 11 & 2.94 & 2.20 & 1.89 & 1.81 & 1.62 & 1.42 & 1.33 \\
\hline 12 & 3.16 & 2.36 & 2.03 & 1.95 & 1.76 & 1.53 & 1.42 \\
\hline 13 & 3.28 & 2.45 & 2.11 & 2.01 & 1.82 & 1.58 & 1.53 \\
\hline 14 & 3.08 & 2.30 & 1.96 & 1.89 & 1.71 & 1.50 & 1.39 \\
\hline 15 & 2.83 & 2.00 & 1.72 & 1.64 & 1.57 & 1.36 & 1.28 \\
\hline 16 & 2.51 & 1.82 & 1.62 & 1.54 & 1.40 & 1.22 & 1.04 \\
\hline 17 & 1.74 & 1.30 & 1.12 & 1.07 & 0.97 & 0.85 & 0.78 \\
\hline 18 & 0.98 & 0.71 & 0.60 & 0.58 & $\mathbf{0 . 5 3}$ & 0.47 & 0.38 \\
\hline Total & 27.48 & 20.35 & 17.51 & 16.76 & 15.24 & 13.93 & 12.28 \\
\hline Mean & 2.50 & 1.85 & 1.59 & 1.52 & 1.39 & 1.27 & 1.12 \\
\hline
\end{tabular}

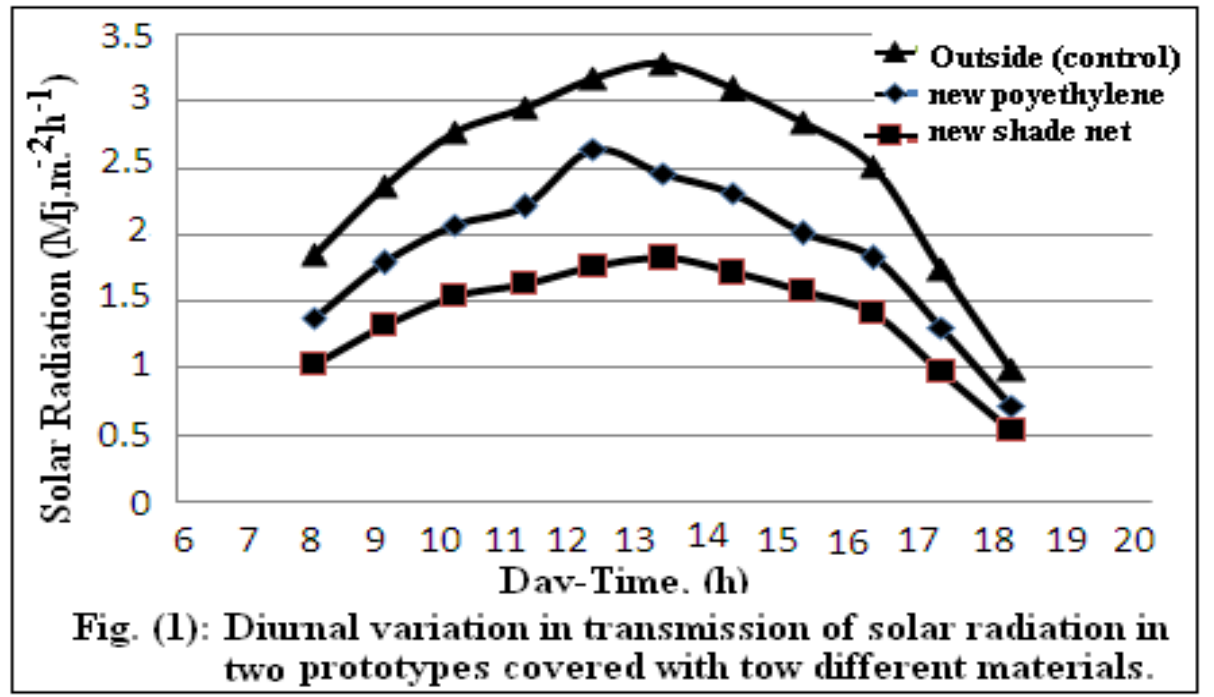

1.2. Effect of aged cover types on transmittance of solar radiation: As shown in Table (2) and Figures (2) and (3), the hourly average transmitted global solar radiation (GSR) for all greenhouse prototypes covered by a 
single layer polyethylene films were always higher than the corresponding values for the greenhouse prototypes covered by black screen shade net sheets. The hourly average transmitted rates of GSR for the new, old-cleaned and old-dirty polyethylene films were $74.05 \% \%$, $60.09 \%$ and $56.41 \%$, respectively. The corresponding values for the new, old-cleaned and old-dirty black screen shade net sheets were $55.45 \%$, $42.52 \%$ and $36.03 \%$, respectively. Consequently, we can say that, exposing the poly-greenhouse cover to the environment reduces the transmittance values of global solar radiation. This is primarily because dust and dirt deposited on the plastic cover absorbed and reflected some of the solar radiation which can pass through it, and thus, loss of radiation transmission can effectively lower the greenhouse-cooling load. On the other hand, decreasing the greenhouse-cooling load is very beneficial in term of reducing the stress on plants and solar energy accumulation inside the planted greenhouse, especially in arid conditions with high radiation load. This can improve fruit quality such as reducing air temperature, sunburn and reduce leaf. Also, color darkening of greenhouse cover caused by exposure to the environment blocked a portion of the incident solar radiation. On the other hand, the loss of solar radiation transmission through the greenhouse cover caused by the observed deposition of dust and dirt particles, beside the color darkening of the cover would minimize the capability of the covering to transmit light in wavelengths useful to plants inside the greenhouse.

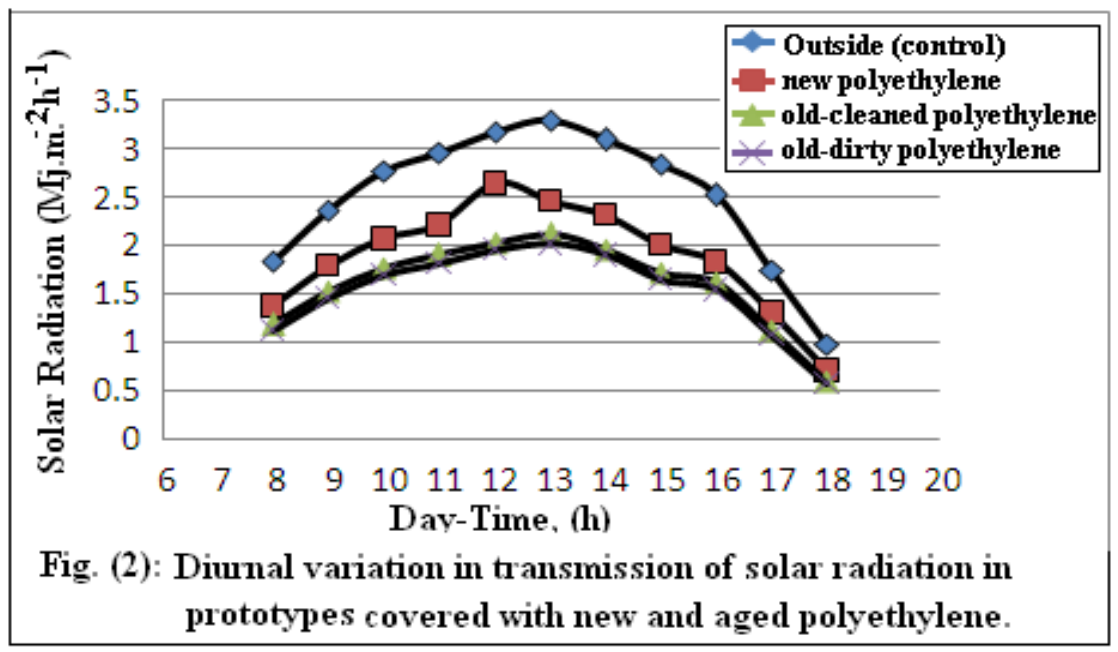




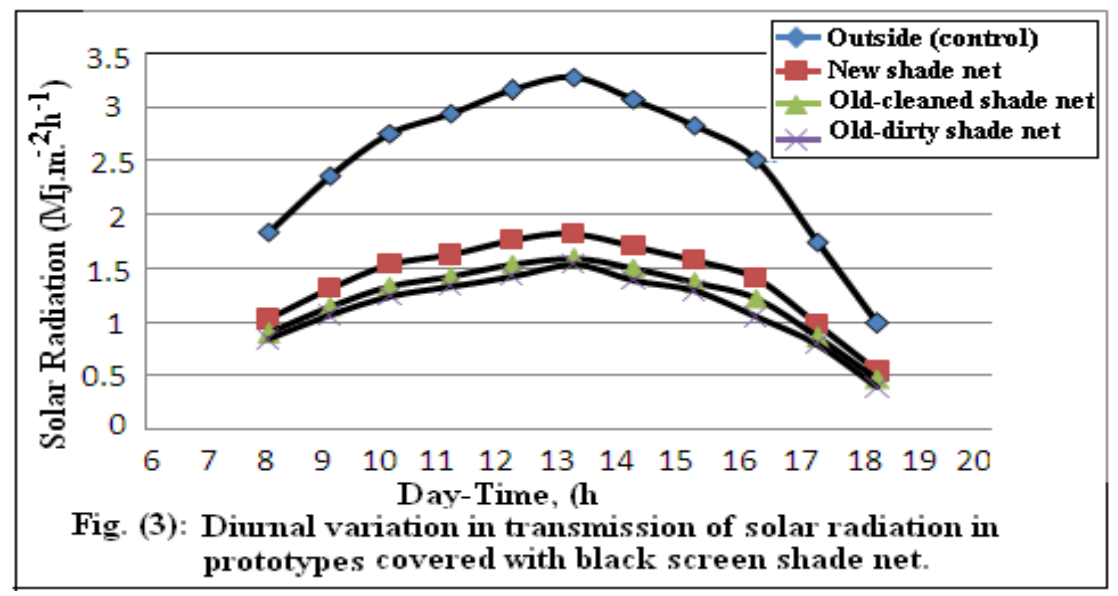

\section{Light Intensity:}

2.1. Effect of new cover types on interior light intensity: Fig. (4) shows the effect of poly-greenhouse covering type on its interior light intensity, during the experimental period. It's clear that, the hourly average exterior light intensity (ambient) was the highest curve, and the others interior light intensities in the poly-greenhouse prototypes with/and without shading were under the ambient light data during the experimental period. It's known that, shading decrease the light intensity, as shown in Fig. (4). The maximum data of the hourly average light intensity was recorded during midday (from 12 noon to $2 \mathrm{pm}$.) for the ambient and the six greenhouse prototypes covered by different types of polyethylene films and shade net sheets. Therefore, the new white polyethylene films and new black screen shade net sheets reduced the hourly average interior light intensity inside the greenhouse prototypes by an average of $18.3 \%$ and $68.4 \%$ as compared with the average exterior light intensity, respectively.

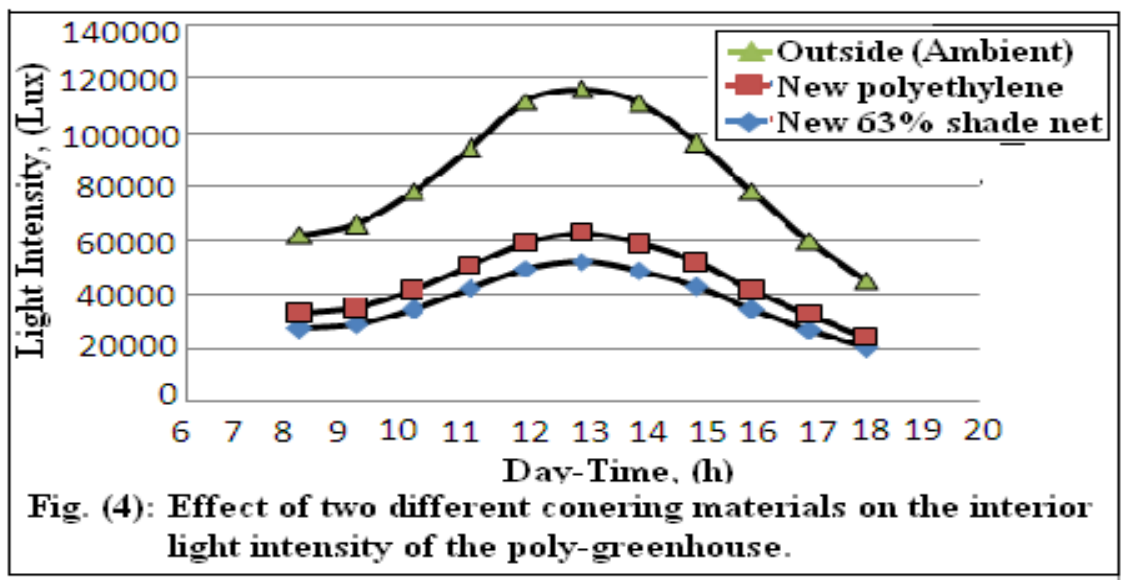


2.2. Effect of aged cover types on interior light intensity: The hourly average interior light intensity behavior under new and old greenhouse covers for the poly-greenhouse prototypes covered with polyethylene films and shade net sheets was appeared at Figures (5) and (6), during the daytime of May, 2012. As shown in the two Figures, it's clear that, all the greenhouse prototypes have interior light intensity lower than the ambient (outside) light intensity. Also, it's clear that; the hourly average light intensity inside all the poly-greenhouse prototypes covered with a single layer of polyethylene films were higher than the corresponding values inside the poly-greenhouse prototypes covered with shade net sheets. It's clear that; the hourly average light intensity inside the poly-greenhouse prototype covered with new single layer polyethylene films ( $\mathrm{T}_{\text {un-sh }}$, zero shading) and the new black screen shade net, had a major recorded data comparison with the other hourly average light intensity inside the polygreenhouse prototype covered with old-cleaned and old-dirty covers. Also, it's obtained that, the old-cleaned and old-dirty polyethylene films reduced the hourly average interior light intensity by an average of $20.8 \%$ and $34.8 \%$ as compared with the identical new white polyethylene film, respectively. While, old-cleaned and old-dirty black screen shade net reduced the interior light intensity by an average of $27.3 \%$ and $39.9 \%$ as compared with the identical new black screen shade net, respectively

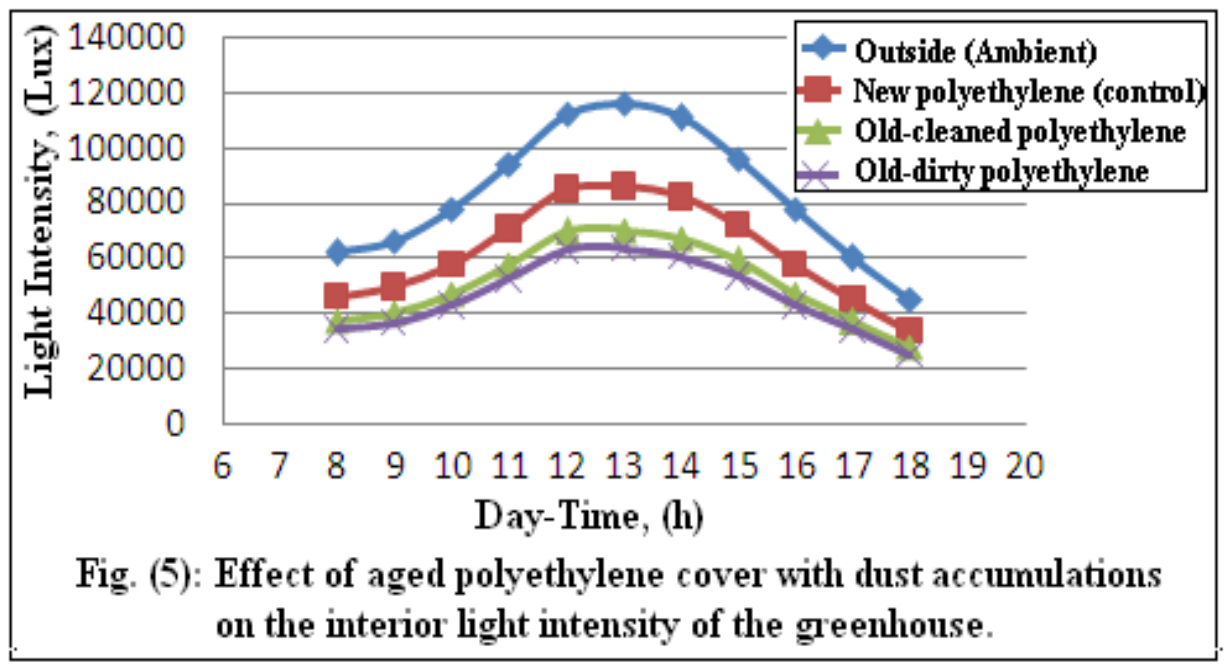




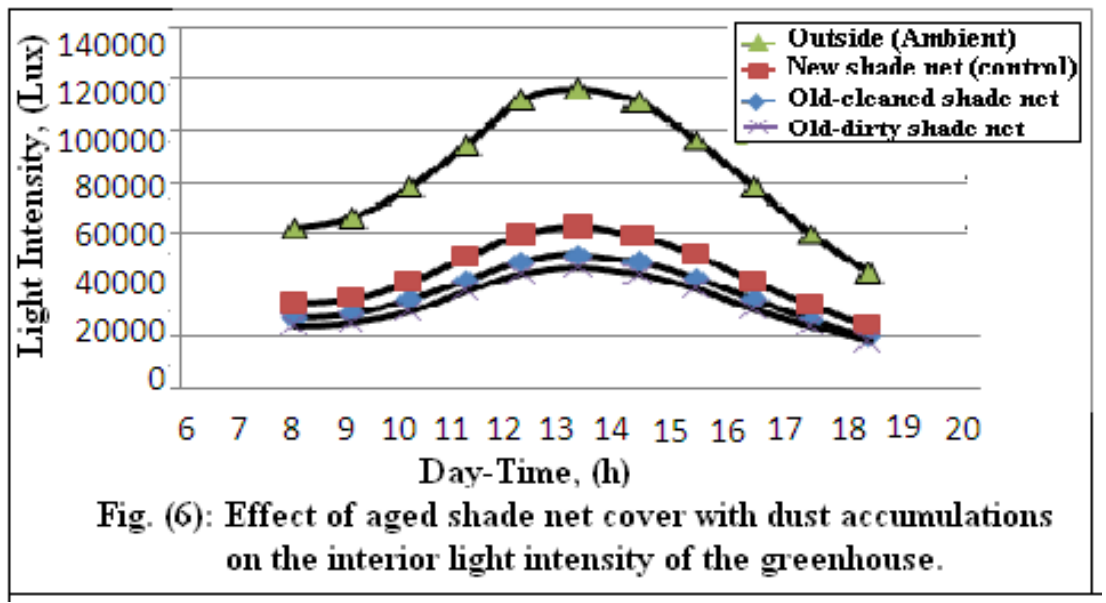

\section{CONCLUSION}

1. The hourly average transmitted global solar radiation (GSR) in both new white polyethylene films and new black screen shade net sheets (63\% shading ratio) were $74.05 \%$ and $55.45 \%$, respectively.

2. Shading caused to decrease the transmittance of solar radiation, and thus, decrease the light intensity, temperatures and others environmental parameters inside the greenhouse during the daytime from sunrise to sunset, and thus, shading can be adequate and satisfactory for growth and production of some plants during the hot weather, especially at the summer months.

3. Exposing the poly-greenhouse cover to the environment reduces the transmittance values of global solar radiation, and thus, the loss of solar radiation transmission through the greenhouse cover caused by the observed deposition of dust and dirt particles, beside the color darkening of the cover would minimize the capability of the covering to transmit light in wavelengths useful to plants inside the greenhouse.

4. The new white polyethylene films and new black screen shade net sheets reduced the hourly average interior light intensity inside the greenhouse prototypes by an average of $18.3 \%$ and $68.4 \%$ as compared with the average exterior light intensity, respectively.

5. The old-cleaned and old-dirty polyethylene films reduced the hourly average interior light intensity by an average of $20.8 \%$ and $34.8 \%$ as compared with the identical new white polyethylene film, 
respectively, while, old-cleaned and old-dirty black screen shade net reduced the interior light intensity by an average of $27.3 \%$ and 39.9 $\%$ as compared with the identical new black screen shade net, respectively

6. The decision on selecting a poly-greenhouse cover must include its physical properties of solar radiation and light transmission and heat transfer, as well as its construction, maintenance, and operational requirements.

\section{REFERENCES}

Abdel-Galil, H. S. (2010). Effect of Poly-greenhouse Shading Ratios on Germination and Yield of Tomato under Fayoum Depression Climatic Conditions. The $17^{\text {th }}$ Annual Conference of the Misr Society of Ag. Eng., 27 (4):2048-2068.

ARGUS CONTROL SYSTEMS LTD. (2010). Light and Lighting Control in Greenhouses. Argus Control Systems LTD., 1281, Johnston Road, White Rock, British Columbia, Canada, V4B 3 Y9.

El-Nono, M. A. ; Habib, Y. A. and El-Sayed R. A. (2008). The Impact of the Polyethylene Greenhouse Cover Properties on Average Indoor Light Intensity. Misr J. Ag. Eng., 25 (1):176 -184.

Jaffrin, A. ; Morisot, A. and Gratraud, J. (1993). Be' ne' fice D' um Nettoyage des Surfaces Externs de Films de Covertures de Serres. (Advantage of Cleaning the External Film Surfaces of Greenhouse). CPA. 65, Rue de Prony, 75 Paris, Collogue de Colmar.

Larcher, W. (2003). Physiological Plant Ecology. Berlin (Germany): Springer-verlag. P: 513.

Lozano, G. M., ; Gonzalez, D. ; Santos, E. (1996). Growing Lettuce in Greenhouse Clad with Polychromatic Films. Plasticulture 110:1522.

Nijskens, J.; Etour J.; Albrecht, E.; Gratraud, J. and Feuilloley, P. (1990). Comparative Studies on the Aging of Polyethylene film in the Laboratory and in the Practical Use. Plasticulture. 87:11-20. 
Papadakis, G. ; Briassoulis, D. ; Scarascia, M. G. ; Vox, G. Feuilloley, P. and Stoffers, J. A. (2000). Radiometric and Thermal Properties of and Testing Methods for Greenhouse Covering Materials. J. Ag. Eng. Res., 77(1): 7-38.

Pinto, J. R. ; Dumroese, R. K. and Marshall, J. D. (2006). Run for Cover. Whats Covering your Greenhouse and How It Is Affecting Seedling Growth? USDA Forest Proceedings, RMRS. P: 43.

Smith, I. E.; Savage, M. J. and Mills, P. (1984): Shading effects on greenhouse tomatoes and cucumbers. Act. Horticulture (148):491500 .

Steven, C. (2004). Comparing Smart Films. LS Climate Control Pty Ltd, 2/43 Lighting Place, Hornsby NSW 2077. Issue 79.

Wikipedia, the free encyclopedia (2007). Solar greenhouse (technical). http://en.wikipedia.org/wiki/solar_greenhouse (technical).

\footnotetext{
الملخص العربي

تأثير نوع غطاء الصوبة البلاستيكية والتظليل على شدة إضاعتها الداخلية حمدى سالم السيد عبد الجليل

يتطلب إنتاج الثتلات أو نمو النباتات داخل الصوب البلاستيكية درجة إضاءة معينة, حيث يعتبر

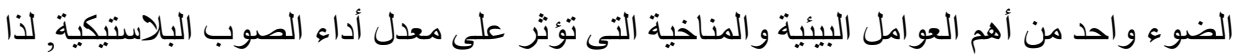

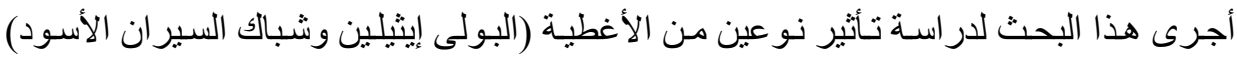

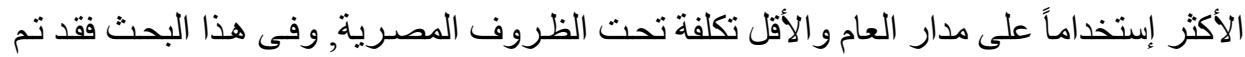
أيضاً إستخدام غطائين قديمين من كل نوع (عمر عام) أحدهما بحالته الطبيعية (متر اكم عليه

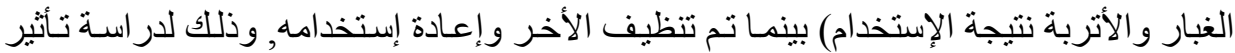

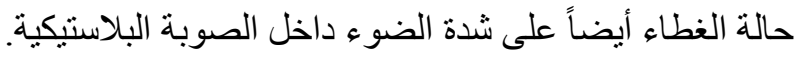

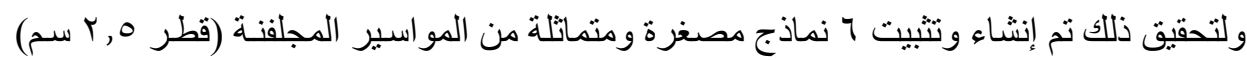

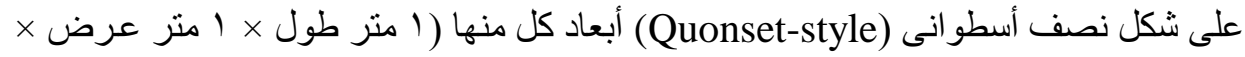

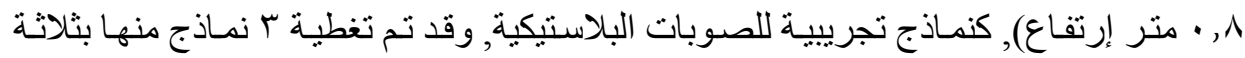

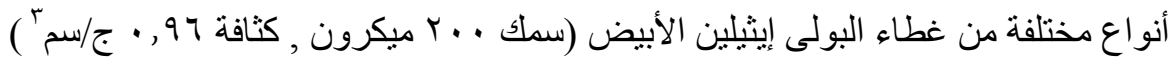
* أستاذ الهتلسة الزراعية المساعد ـ كلية الزراعة ـ جامعة الفيوم. 
أحدهما جديد و الأثنين الأخرين قديمين (عمر عـام) الأول بحالته الطبيعيـة (وسـخ متر اكم عليـه

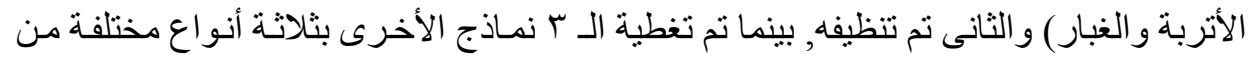

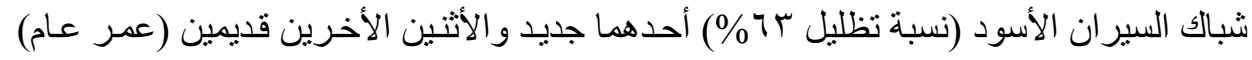

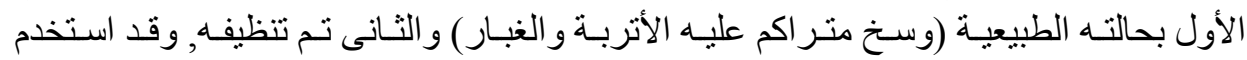
النموذجين المغطيين بالغطاء الجديد فى الحالتين السابقتين للمقارنة. وقد أوضحت النتائج مايلى: ا ـ يعتبر منخفض الفيوم ذو ظروف مناخية خاصة, حيث يوجد تفاوت كبير بين درجـة الحرارة

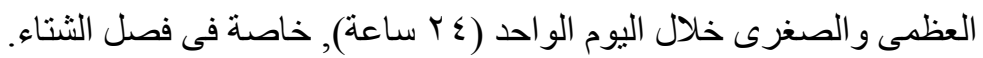

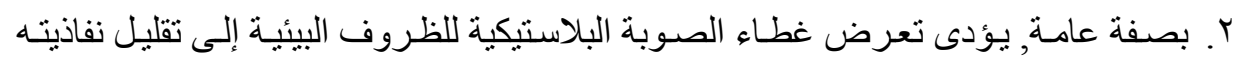

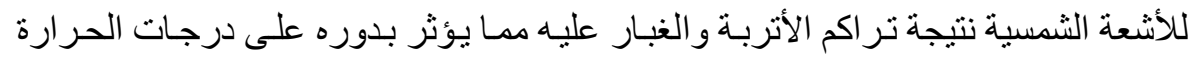
داخل الصوبة.

r. أدى إستخدام غطاء شبالك السير ان الأسود (Thading Ratio - Sh\% إلى تقليل نفاذيـة

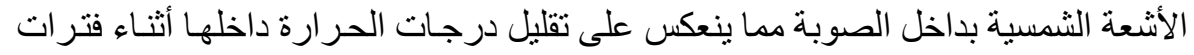
النهار, بينما كان يحدث الإتزان الحرارى بين الصوبة والجو الخارجى أثناء فترات الليل.

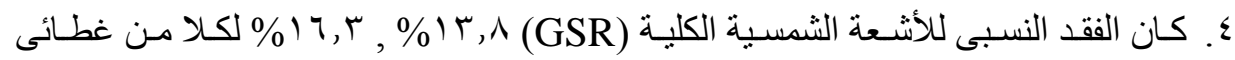
البولى إيثلين الأبيض القديمين (عمر عـام) المنظف و المتسخح على الترتيب مقارنـة بغطـاء

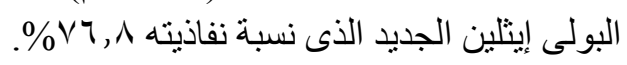

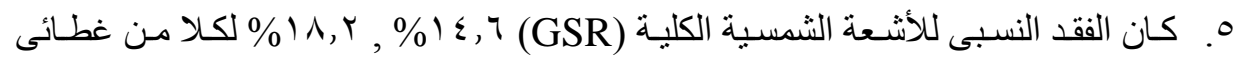

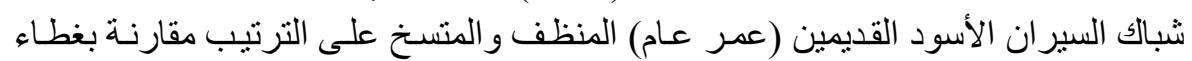

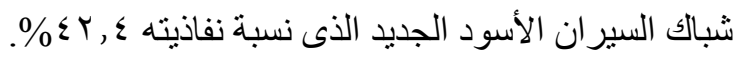

7. أدى إستخدام غطائى البولى إيثلين الأبيض وشبالك السيران الأسـود ( shading Ratio

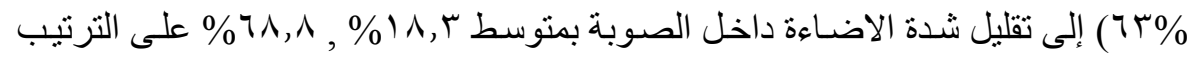
مقارنة بثدة إضناءة الجو الخارجى.

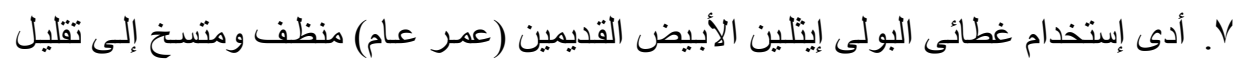

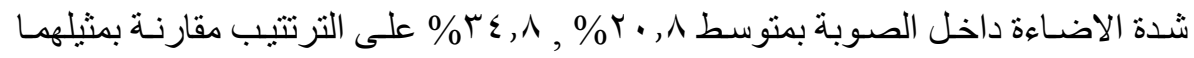

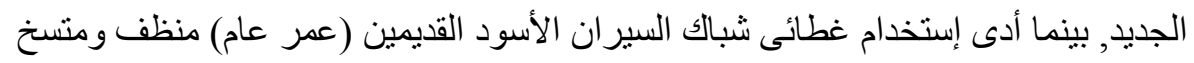

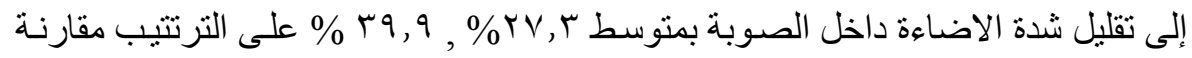
بمثيلهما الجديد.

^. يوصى بضرورة تنظيف غطاء الصوبة البلاستيكية بصفة دورية منتظمة, وذلك حفاظاً على الكى

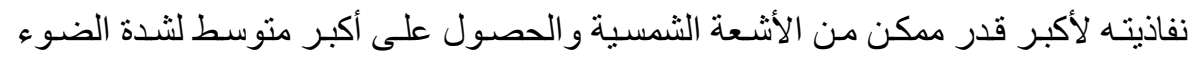

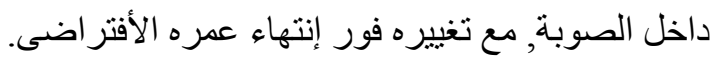

